\title{
Термические отжиги имплантированных мышьяком МЛЭ пленок CdHgTe
}

\author{
И.И. Ижнин ${ }^{1,2)}$, А.В. Войцеховский ${ }^{2)}$, А.Г. Коротаев ${ }^{2)}$, К.Д. Мынбаев ${ }^{3,4)}$, О.Ю. Бончик ${ }^{5)}$ \\ Г.В. Савицкий ${ }^{5)}$, В.С. Варавин ${ }^{6}$, С.А. Дворецкий ${ }^{2,6)}$, Н.Н. Михайлов ${ }^{6}$, В.Г. Ремесник ${ }^{(6)}$, М.В. Якушев ${ }^{6}$, \\ Y. Morgiel ${ }^{7)}$, Z. Świątek ${ }^{7)}$ \\ ${ }^{1}$ Научно-производственное предприятие «Электрон-Карат», Львов, 79031, Стрийская 202 \\ ${ }^{2}$ Национальный исследовательский Томский госуниверситет, Томск, 634050, Ленина 36 \\ ${ }^{3}$ ФТИ им. А.Ф. Иоффе, Санкт-Петербург, 194021, Политехническая 26 \\ ${ }^{4}$ Университет ИТМО, Санкт-Петербург, 197101, Кронверкский 49 \\ ${ }^{5}$ ИППММ им. Я.С. Пидстригача НАН Украины, Львов, 79060, Научная $3 б$ \\ ${ }^{6}$ ИФП СО РАН, Новосибирск, 630090, пр. Ак. Лаврентьева, 13 \\ ${ }^{7}$ Institute of Metallurgy and Material Science PAN, 30-059, Krakow, Reymonta, 25 \\ тел:+38(032) 263-1065, факс:+38(032) 294-9735, эл. почта: i.izhnin@ carat.electron.ua
}

DOI 10.34077/RCSP2019-177

В настоящее время наблюдается значительный прогресс в технологии создания $p^{+}-n$ фотодиодов на основе $\mathrm{Cd}_{\mathrm{x}} \mathrm{Hg}_{1-\mathrm{x}} \mathrm{Te}$ с использованием ионной имплантации мышьяка. Одной из ключевых для данной технологии является операция электрической активации имплантированной примеси, которая обычно проводится путём двухстадийного термического отжига. Первый этап отжига, проводимый при высоких температурах $\left(\sim 360^{\circ} \mathrm{C}\right)$, и имеющий целью активацию мышьяка и аннигиляцию радиационных дефектов, приводит весь материал к дырочному типу проводимости, а в результате второго этапа ( $220{ }^{\circ} \mathrm{C}$ при насыщенном давлении паров ртути) вакансии ртути, созданные на первом этапе, аннигилируют, а сама «база» $p^{+}-n$ перехода возвращается к электронному типу проводимости, обусловленному легированием донорной примесью (как правило, индием), проводимым на стадии выращивания материала. При проведении измерений электрических параметров образовавшейся после отжига $p^{+}-n$ структуры оказывается сложно выделить вклад $p^{+}$-слоя (с имплантированным и активированным мышьяком) в проводимость на фоне высокой проводимости $n$-«базы». Для решения этой проблемы и получения достоверных данных об электрических свойствах создаваемых структур, проведено исследование влияния различных отжигов на свойства имплантированных мышьяком структур на основе $\mathrm{Cd}_{\mathrm{x}} \mathrm{Hg}_{1-\mathrm{x}} \mathrm{Te}$, выращенных методом молекулярно-лучевой эпитаксии на подложках $\mathrm{Si}$. Исследовались три гетероэпитаксиальные структуры с близким химическим составом фоточувствительных слоёв (x=0.22), выращенные в разных технологических циклах.

Ионная имплантация была проведена на установке IMC200 (Ion Beam Services, Франция) однозарядными ионами $\mathrm{As}^{+}$с энергией $E \approx 200$ кэВ и флюенсом $\Phi=10^{14} \mathrm{~cm}^{-2}$. Двухстадийный активационный отжиг проводился в следующих режимах: $360{ }^{\circ} \mathrm{C}, 2$ часа при насыщенном давлении паров ртути $\left(T_{\mathrm{Hg}}=350{ }^{\circ} \mathrm{C}\right)$, и $220^{\circ} \mathrm{C}, 24$ часа, при насыщенном давлении паров ртути $\left(T_{\mathrm{Hg}}=210{ }^{\circ} \mathrm{C}\right)$. Также проводился изотермический отжиг в $p$-тип проводимости, - в атмосфере гелия при температуре $\sim 230{ }^{\circ} \mathrm{C}$ в течение 22 часов. После отжигов исследовались спектры отражения, ПЭМ исследования приповерхностной дефектной области и электрических параметров структур.

В результате исследований было установлено, что тип проводимости имплантируемого образца $(n-$ или $p$-) не влияет на характер радиационного дефектообразования (формирование дефектов вида «междоузельная ртуть, захваченная дислокационной петлей»). Связывания атомов мышьяка на дислокационных петлях, в свою очередь, нами обнаружено не было. В результате активационного отжига наблюдалась аннигиляция дислокационных петель и связанных с ними радиационных донорных дефектов, ответственных за появление электронов с низкой подвижностью. Как было установлено, активационный отжиг приводит к образованию поверхностного (толщиной порядка величины полного пробега ионов, 300 нм) слоя $p$-типа проводимости с высокой степенью активации мышьяка. Возможный механизм активации - распад стеклообразных центров вида $\mathrm{As}_{2} \mathrm{Te}_{3}$, в которые мышьяк связывается после имплантации. 